\title{
Evaluation of oropharyngeal infections in febrile neutropenic patients: a study of 335 episodes
}

\section{Febril nötropenik hastalarda orofarengeal enfeksiyonların irdelenmesi: 335 ataklık çalışma}

\author{
Firdevs Aksoy' ${ }^{1}$, Iftihar Koksal ${ }^{1}$ \\ ${ }^{1}$ Dept. of Infectious Diseases and Clinical Microbiology, Karadeniz Technical University, Faculty of Medicine, Trabzon, Turkey
}

\begin{abstract}
Objective In neutropenic patients, mucositis can occur in the entire gastrointestinal tract, especially in the oropharynx. Disruption of mucosal integrity provides the basis for local invasion and causes it to become an important focus of infection. The aim of this study was to draw attention to the importance of oral cavity examination and evaluation of oropharyngeal infections in patients with febrile neutropenia (FN).

Methods Demographic data, number of episodes, distribution of malignancies and developing oropharyngeal infections of febrile neutropenic patients with hematologic malignancies in a tertiary hospital over a three-year period were evaluated.

Results A total of 170 patients with 335 FN episodes were included in our study. Bacteremia was the most common microbiologically documented infection $(n=92,27.5 \%)$. the second most common infection was oropharyngeal infections $(n=69,20.1 \%)$. The most common microorganism isolated from oropharyngeal infections was fungi $(n=34$, $49.3 \%)$.

Conclusions Oropharyngeal infections of febrile neutropenic patients may cause localized and systemic infections. Daily examination and care of the oral cavity of the patients should be done with care. The oropharyngeal flora should be closely monitored and it should be considered that the flora may also be a source in case of a possible infection.
\end{abstract}

Key words: febrile neutropenia, oropharyngeal infections

\section{O̊zet}

Amaç Nötropenik hastalarda mukozit orofarenks başta olmak üzere tüm gastrointestinal sistemde oluşabilmektedir. Mukoza bütünlügünün bozulması lokal invazyona zemin hazırlar ve önemli bir enfeksiyon odağı haline gelmesine neden olur. Bu çalışmada febril nötropenik hastalarda gelişen orofarengeal enfeksiyonların değerlendirilmesi ve oral kavite muayenesinin önemine dikkati çekmek amaçlanmıştır.

Yöntem Tersiyer bir hastanede üç yıl boyunca tanı alan hematolojik maligniteli febril nötropenik hastaların demografik verileri, atak sayısı, malignitelerin dağılımı ve gelişen orofarengeal enfeksiyonlar değerlendirildi.

Bulgular Toplam 335 atak geçiren 170 hasta çalışmaya dahil edildi. Mikrobiyolojik olarak dökümante edilen enfeksiyonlarda en sık bakteremi (n=92, \%27.5) vardı. İkinci en sık enfeksiyon orofarengeal enfeksiyonlardı (n=69, \%20.1). Orofarengeal enfeksiyonlardan en sık izole edilen mikroorganizma funguslardı ( $\mathrm{n}=34, \% 49.3)$.

Corresponding author: Firdevs Aksoy, Dept. of Infectious Diseases and Clinical Microbiology, Karadeniz Technical University, Faculty of Medicine, Trabzon, Turkey, Phone: +90 46237756 63, E-mail: faslanaksoy@yahoo.com

Received: 24 June 2019 Accepted: 28 June 2019

Conflicts of Interest: None

Funding: Karadeniz Technical University Scientific Research Projects 
Sonuç Febril nötropenik hastaların orofarengeal enfeksiyonları lokalize ve sistemik enfeksiyona ilerleyen klinik tablolara neden olabilir. Hastaların oral kavitesinin günlük muayenesi, bakımı özenli bir şekilde yapılmalıdır. Orofarengeal floraları yakın takip edilmeli ve olası bir enfeksiyon tablosunun olduğu durumlarda buradaki floranın da kaynak olabileceği mutlaka göz önünde bulundurulmalıdır.

\section{Anahtar kelimeler: febril nötropeni, orofarengeal enfeksiyon}

\section{Introduction}

Febrile neutropenia (FN), which is defined as fever and malignancy syndrome, is a clinical condition that develops from self-limiting benign episodes to life-threatening infections in immunosuppressive patients, especially after chemotherapy in malignant patients. Neutropenia, which is the result of chemotherapeutic drugs suppressing bone marrow, is the most important factor in preparing the ground for infection in patients with malignancy. The frequency and severity of infection are related to the depth and lengthening of neutropenia. In addition, dysfunctions of neutrophils that may develop as a result of chemotherapy or due to underlying disease increase the tendency to infection. Mucositis, which is one of the most important complications of chemotherapy applications, also prepares the ground for the development of infection. Mucositis, particularly in the oropharynx, can occur in the whole gastrointestinal system. Disruption of mucosal integrity, by providing the basis for local invasion of bacteria, fungi and viruses, causes the inside of the mouth to become an important focus of infection in FN cases. In this patient group, where nausea, vomiting and epigastric complaints are common, frequent use of antacid, H2 receptor blockers and proton pump inhibitors eliminates the natural acid barrier of the stomach and facilitates colonization of intestines with resistant microorganisms from the hospital environment. With the deterioration of mucosal integrity after chemotherapy, especially Gram-negative enteric rods and other Gram-negative rods, especially Pseudomonas aeruginosa, may be mixed with blood by translocation and cause bacteremia and sepsis. ${ }^{1-5}$

The most common source of infection in patients with FN is the gastrointestinal system. Mucosal damage resulted from chemotherapy causes invasion of microorganisms. At the end, bacteremias caused by endogenous bacteria occur. In addition, permanent catheters, leading to deterioration of skin integrity, are common insertion sites for microorganisms. Patients with FN should be questioned and examined in detail according to the systems. Periodonteum, pharynx, oral mucosa, lung, perineum, anus, skin, catheter insertion site, bone marrow aspiration sites, nail fold, fundus examination should be evaluated. Inflammation signs and symptoms may be faint or absent in patients with anemia. Therefore, skin infections can be seen without signs of induration, erythema and pustule. Patients with FN are at risk for various complications and infections, including the development of mucositis and oral ulcers. Changes in oral flora during chemotherapy and the development of oropharyngeal infection are frequently encountered. ${ }^{1-5}$

The aim of this study was to draw attention to the importance of oral cavity examination and evaluation of oropharyngeal infections in patients with FN.

\section{Methods}

In this study, patients with FN who underwent induction or consolidation for hematological malignancy, and who developed FN due to aplastic anemia were included in the study. Patients receiving allogeneic / autologous stem cell transplantation and therefore receiving induction or consolidation therapy, or receiving oral antibacterial, antiviral or antifungal prophylactic drugs were excluded from the study. Demographic data, number of episodes, distribution of hematologic malignancies and developing infections of the patients were evaluated. Ethic approval was obtained from local ethic committee (14.02.2008-3/05)

Demographic information, concurrent diseases, underlying disease and disease status, chemotherapy protocol, presence of catheter, all other medications, duration of neutropenia, neutrophil level of patients with FN episodes who meet the criteria for patient admission were recorded in 'Febrile Neutropenic Patient Follow-up Form' before the initiation of antimicrobial treatment. Cultures from all focus for which infection was consid- 
ered and at least two blood cultures were obtained. Daily physical examinations of the patients were performed in detail until the end of the attack. Blood counts, biochemical tests (urea, creatinine, alkaline phosphatase, lactic dehydrogenase, transaminases, liver function tests and electrolytes), urine analysis and chest x-ray were repeated based on clinical evaluations. Blood counts and biochemical parameters were monitored daily. In case of signs of oropharyngeal mucosal infection, smear, gram staining and culture and throat culture were performed. Aspiration, smear, gram staining and culture were performed in patients with mucous membrane and skin lesions. When indicated, culture and histopathological examination was performed by invasive aspiration, biopsy or drainage. Colonization and infection distinction was taken into consideration in defining the focus of infection. Identification and antibiotic susceptibility of microorganisms were performed in the hospital microbiology laboratory using BD Phoenix automated microbiological system (Becton Dickinson, Sparks, Md) and standardized methods. Empirical antibiotic treatment was started immediately after the cultures were taken.

Infections of patients with FN were evaluated in three groups as microbiologically documented infection (MDI), clinically documented infection (CDI) and fever of unknown origin (FUO). ${ }^{2,7}$

In the Statistical Analysis, the data obtained by measurement were shown as arithmetic mean \pm standard deviation, and the data obtained by counting were shown as numbers (\%).

\section{Results}

In the study, $335 \mathrm{FN}$ episodes developed in 170 patients over a three-year period. The mean age of males was $41.4 \pm 13.4$ (17-82) and the mean age of the females was $42.0 \pm 15.9$ (16-79) years.

Of the 335 episodes; 170 (50.7\%) were first episode, 93 (27.8\%) were second , 46 (13.7\%) were third, 23 (6.9\%) were 4 th episode and $3(0.9 \%)$ were the 5 th episode. When the underlying diseases were examined, acute leukemia (60.9\%) was the first and followed by lymphomas $(24.0 \%)$. The rate of other hematologic and aplastic anemia was $15.2 \%$.
When the causes of fever were examined; 187 (55.9\%) episodes of MDI; 67 (20.0\%) of CDI; 81 (24.1\%) episodes of FUO was detected. Among the MDIs, the most common was bacteremia ( $n=92), 58$ of them had positive blood culture positivity without any other focus. The second common was oropharyngeal infections $(n=69)$. The distribution of MDIs according to the systems in patients shown in table 1 . Some patients had multiple infections during FN episodes and 247 different microorganisms were isolated from different foci. In microorganisms; the rate of gram positive was $27.8 \%$ ( $n=93)$, gram negative was $25.1 \%(n=84)$, fungi was $18.2 \%(\mathrm{n}=61)$, and $2.4 \%$ had polymicrobial growth. The distribution of microorganisms according to the foci they were isolated is shown in figure 1 .

In blood cultures, from gram negative microorganisms, E.coli was most frequently isolated and Klebsiella pneumoniae was the second common organism. Methicillin-resistant coagulase-negative staphylococci (MRCNS) were the most common microorganisms (5.4\%) of gram positive microorganisms. Polymicrobial microorganism was isolated in four episodes (4.3\%). When fungemias were examined, Candida tropicalis was isolated in 3 patients, Aspergillus spp. in one and Trichosporon asahii in one patient.

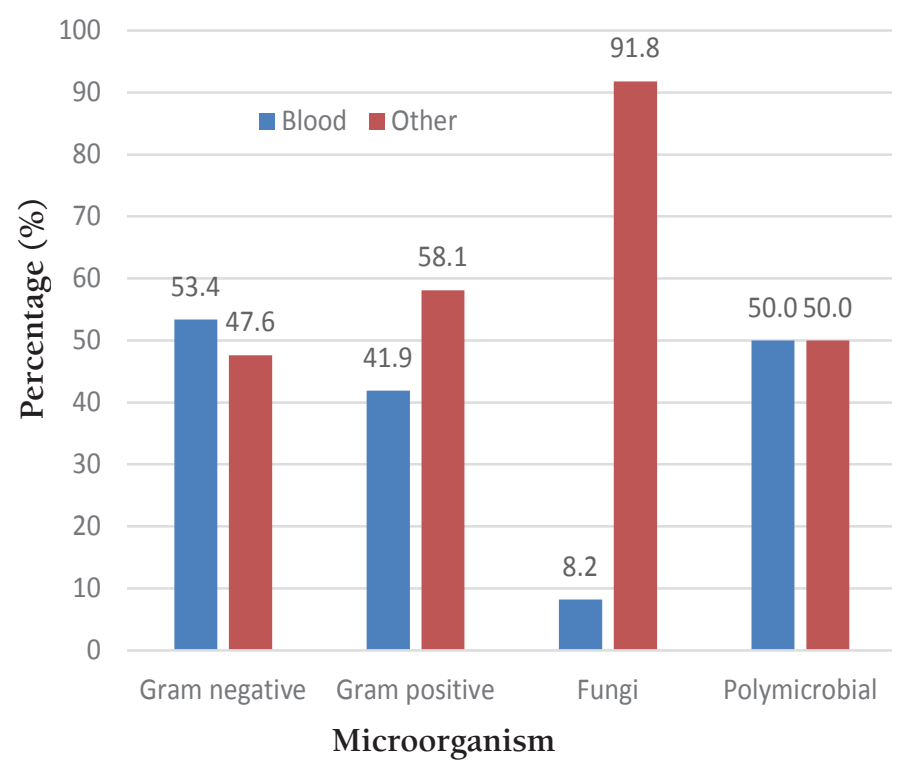

Fig. 1. Isolation rates of microorganisms according foci 
Table 1. Distribution of microbiologically documented infections (MDI) according to systems

\begin{tabular}{lccc}
\hline $\begin{array}{c}\text { Focus of } \\
\text { infection }\end{array}$ & $\begin{array}{c}\text { Number of } \\
\text { episodes (n) }\end{array}$ & $\begin{array}{c}\text { Ratio in } \\
\text { MDIs } \\
(\%)\end{array}$ & $\begin{array}{c}\text { Rates of all } \\
\text { episodes(\%) }\end{array}$ \\
$\begin{array}{lccc}\text { Bacteraemia } \\
\begin{array}{l}\text { Oropharyngeal } \\
\text { infections }\end{array}\end{array}$ & 69 & 49.2 & 27.5 \\
UI & 33 & 17.6 & 9.9 \\
RI & 17 & 9.1 & 5.1 \\
$\begin{array}{l}\text { Other } \\
\begin{array}{l}\text { Total } \\
\text { (microorganism) }\end{array}\end{array}$ & 246 & 19.3 & 10.7 \\
\hline
\end{tabular}

UI, Urinary infections ; RI, Respiratory infections

In cultures taken from other foci Gram positive microorganisms were observed $17.3 \%$ among all episodes, were mostly isolated from oropharyngeal infections $(n=28)$. The rate among MDI as $14.9 \%$ and of all episodes were $8.4 \%$. The rates of gram negative microorganisms isolated from oropharyngeal infections $(n=7)$ were lower. The rate among MDIs was 3.7\% and the rate of all episodes was $2.1 \%$. In cultures taken from non-blood foci the fungi were isolated from the oropharyngeal region. The most

Table 2. Microorganisms isolated from oropharyngeal lesions

\begin{tabular}{lccc}
\hline $\begin{array}{l}\text { Microorganisms } \\
\text { isolated from } \\
\text { oropharyngeal } \\
\text { lesions }\end{array}$ & $\begin{array}{c}\text { Number of } \\
\text { episodes } \\
(\mathbf{n})\end{array}$ & $\begin{array}{c}\text { Ratio in } \\
\text { MDIs } \\
(\%)\end{array}$ & $\begin{array}{c}\text { Rate of all } \\
\text { episodes } \\
(\%)\end{array}$ \\
$\begin{array}{l}\text { Fungi } \\
\text { Gram positive } \\
\text { microorganisms }\end{array}$ & 28 & 14.9 & 8.4 \\
$\begin{array}{l}\text { Gram negative } \\
\text { microorganisms }\end{array}$ & 7 & 3.7 & 2.1 \\
Total & 69 & 36.8 & 20.6 \\
\hline
\end{tabular}

frequently isolated microorganism from oropharyngeal infections was fungi ( $\mathrm{n}=34,49.3 \%)$. The rate in MDIs was $18.1 \%$ and the rate in all episodes was $10.1 \%$. The most commonly isolated microorganism was C.albicans. The development of esophagitis was defined endoscopically in two isolated episodes of candida. The same microorganisms were isolated in esophageal endoscopic biopsy material. The distribution of microorganisms isolated from oropharyngeal lesions is shown in table 2 .

The number of CDI was 191 (57.0\%), of which 124 (37.0\%) also had MDI. 67 (20.0\%) exacerbations had CDI alone without MDI. In CDIs; skin soft tissue infections were the most common ( $\mathrm{n}=14,20.9 \%)$, while oropharyngeal infections were in the fourth $(n=9,13.4 \%)$.

\section{Discussion}

Intensive chemotherapy regimens used in the treatment of hematological malignancies resulted in an increase in the incidence of FN. Uncontrolled infections still consitute the most frequent cause of mortality. Problems in the diagnosis of infections in these patients as well as opportunistic pathogens that do not lead to infections in immunocompetent individuals and antimicrobial treatment modalities to be used in such circumstances are still under investigation. ${ }^{1-7}$

The underlying diseases in FN patients with hematological malignancies are various. In the present study, analysis of $335 \mathrm{FN}$ episodes yielded that $60.9 \%$ patients had acute leukemia, $24.0 \%$ patients had lymphoma and $11.0 \%$ of cases were diagnosed with aplastic anemia and other hematological malignancies. Rossini, Cherrif and Viscoli have determined that acute leukemia (53.0\%$62.0 \%)$ and lymphoma (22.0\%-27.0\%) were the most common underlying diseases in patients in their reports. ${ }^{11-13}$ Thus, our results are consistent with data in relevant literature.

Investigation of infection foci in FN episodes indicated prevalences of MDI, CDI and FUO as $14.0 \%-47.0 \%$, $7.0 \%-27.0 \%$, and $34.0 \%-57.0 \%$, respectively. ${ }^{14-21}$ In Turkey, the prevalences of MDI and CDI were found as $34.0 \%$ and $14.0 \%$, respectively. ${ }^{22}$ Aydın et al. reported 
that prevalence of MDI was $18.4 \%$, whereas prevalences of CDI and FUO were $27.6 \%$ and $53.9 \%$, respectively. ${ }^{20}$ Our results for CDI were in accordance with data in relevant literature, while our prevalence for MDI was higher and that for FUO was higher than that in the current publications. We have closely followed up our patients in this series and physical examination as well as laboratory results were carried out on a daily basis. Patients were evaluated by departments of hematology and infectious diseases twice a week and invasive and non-invasive diagnostic methods were utilized without delay. This meticulous approach may have contributed to the accomplishment of lower rates of FUO, while MDI rates may have increased in parallel to this alteration. This circumstance may be closely related with increased rates of documented infections in our tertiary care center.

In 1970s, gram (-) bacteria were more common causes of infections in FN patients, whereas gram (+) pathogens including coagulase (-) staphylococi started to supervene in etiology in 1980s. At the end of 1990s, rates of isolation of gram (+) and gram (-) microorganisms were similar. However, in 2000s, gram (-) microorganisms started to predominate in the microbiology of FN patients. ${ }^{23}$ We have described MDI in 187 episodes and a total of 247 microorganisms were isolated in these circumstances. The distribution of microorganisms were as follows: Gram (+) bacteria in $27.8 \%$ of cases, Gram (-) bacteria in $25.1 \%$ of cases, fungi in $18.2 \%$ and polymicrobial agents in $2.4 \%$ of patients. In one attack, $\mathrm{M}$. tuberculosis $(0.3 \%)$ was identified. Even though rates of Gram (+) microorganisms were higher than that of Gram (-) pathogens, the difference between them was statistically insignificant. The reason for relatively higher rate of gram (+) microorganisms may be due to the joint evaluation of all culture results.

The prevalence of bacteremia in FN patients with hematological malignancies was $30 \%-40 \%$ and bacteremia constitutes the most common cause of mortality due to infection. ${ }^{24}$ The most common foci of infection in FN patients are lungs, urinary system, skin, soft tissue and gastrointestinal system and the most common pathogens are gram (-) microorganisms.
Analysis of polymicrobial pathogens which constitute up to $23 \%$ of cases demonstrated that the majority of these pathogens consisted of gram (-) microorganisms. ${ }^{25}$ In our study, bacteremia (49.2\%) and oropharyngeal infections comprised the main componenets of MDIs.

Fungi were the most common pathogens in oropharyngeal infections. The microorganisms that were isolated in case of fever were taken into account to distinguish colonization and infection. The sources of infection detected in our series are in parallel to those in literature, while the order of frequency differs from that in relevant publications.

Prolonged neutropenia, mucosal injury, use of wide spectrum antibiotics, steroid use, central venous catheterization, total parenteral nutrition and deterioration of cellular immunity are factors that lead to increased frequency of fungal infections in FN patients. ${ }^{26}$ Superficial and opportunistic fungal infections are more frequent in these patients. Oropharyngeal candidiasis, oesophageal, sinopulmonary, rhinocerebral, hepatosplenic and central nervous system infections are the main forms of these infections. ${ }^{27,28}$ Candida subtypes are yeasts that colonize gastrointestinal system, skin and upper respiratory tract and only $10 \%$ of them are pathogens. Life-theratening invasive and systemic infections are rare, but they may cause mortality in immunosuppressive patients. ${ }^{29}$

The series by European Organization for Research and Treatment of Cancer demonstrated that the most common foci of infection were oropharynx (25\%), lower respiratory tract $(25 \%)$, skin, soft tissue and catheter (15\%), gastrointestinal system (15\%), perianal region (10\%), urinary system (5-10\%), and nose \& paranasal sinuses $(5 \%){ }^{30}$ In our study, fungi was isolated from blood (8.2\%) and other foci (91.8\%). These rates are consistent with data from relevant literature. In terms of foci other than blood, the most common source of candida was oropharynx. The rates of candidal isolation for MDI and all infection episodes were $18.1 \%$ and $10.1 \%$, respectively. Fungi were the most common type of pathogens isolated in oropharyngeal infections (49.3\%). It is difficult to distinguish whether oral candidiasis is a true infection or colonization in FN patients. ${ }^{31}$ Guven et al. 
reported that oral/oesophageal candidiasis were detected in 30\% of 167 MDI patients. ${ }^{32}$

Kandemir et al. determined only 23 MDI cases in their FN series of 81 patients and oropharyngeal candidiasis was detected in only 1 (4.3\%) patient..$^{33}$ Oropharyngeal fungal infections usually occur in the period with long-term and deep neutropenia of FN patients. Pathogens may lead to colonization or symptomatic infections, which may subsequently become systemic infections. Therefore, dental and oral cavity examinations must be carefully performed and oral hygiene must be provided. These precautions may avoid development of infectious complications in FN patients.

Establishment of appropriate diagnosis and timely initiation of antifungal treatment are critical to diminish rates of morbidity and mortality in FN patients. ${ }^{34}$ Oropharyngeal region was the most common focus where candida spp. were isolated. The rates of isolation of fungi from lesions was highest in all episodes (10.1\%). The control of fever with antifungal treatment in patients with candida isolated from oropharyngeal region that demonstrate pseudohyphae under direct microscopy and with no other possible foci were accepted as candida infection. The most common fungal agent was $C$. albicans.

Although oropharyngeal infections are usually linked with oral floral bacteria, chemotherapies, immunosuppression and concomitant mucosal injury may contribute to gram $(+)$ or gram (-) infections. ${ }^{8,35,36}$ We have also isolated gram $(+)$ and gram (-) infections from oropharyngeal infections in this study.

\section{Conclusion}

Oropharyngeal infections may give rise to clinical scenes progressing to localized and systemic infections in FN patients. Daily examination and care of oral cavity must be implemented in these patients. The composition of oral flora must be closely observed and association between oral flora and any infection must not be ignored.

\section{References}

1. Febril nötropenik hastalarda tanı ve tedavi kılavuzu.
Flora 2004;9:5-28.

2. Freifeld AG, Bow EJ, Sepkowitz KA, et al. Clinical practice guideline for the use of antimicrobial agents in neutropenic patients with cancer: 2010 update by the infectious diseases society of America. Clin Infect Dis 2011;15:52.

3. Özsüt H. İmmünsupresif konakların değerlendirilmesi ve görülen enfeksiyonlar. Febril Nötropeni. Bilimsel tıp. (Akova M, Akan H, eds). Ankara, 2010;9-17.

4. https://www.ajmc.com/journals/supplement/2017/ clinical-advance-in-the-management -of-febrile-neutropenia/guidelines-in-the-management-of-febrile-neutropenia-for- clinical-practice.

5. Paesmans M, Kern WF. Tüm nötropenik hastalar aynı mı? Febril Nötropeni. Bilimsel tıp. (Akova M, Akan H, eds). Ankara, 2010;63-72.

6. Hughes WT, Armstrong D, Bodey GP, et al. Guidelines for the use of antimicrobial agents in neutropenic patiens with unexplained fever. Clin Infect Dis 2002;34:730-51.

7. Saba R. Febril nötropenik hastalarda klinik değerlendirme. Febril Nötropeni. Bilimsel tıp. (Akova M, Akan H, eds). Ankara, 2010;97:101.

8. Napenas JJ, Brennan MT, Bahrani-Mougeot FK. Relationship between mucositis and changes in oral microflora during cancer chemotherapy. Oral Surg Oral Med Oral Pathol Oral Radiol Endod 2007;103:48-59.

9. Wong HM. Oral complications and management strategies for patients undergoing cancer therapy. Sci World J 2014;581795.

10. Van der Velden WJ, Herbers AH, Netea MG. Mucosal barrier injury, fever and infection in neutropenic patients with cancer: introducing the paradigm febrile mucositis. Br J Haematol 2014;167:441-52.

11. Rossini F, Terruzzi E, Verga L, et al. A randomized clinical trial of ceftriaxone and amikacin versus piperacillin tazobactam and amikacin in febrile patients with hematological neoplasi and severe neutropenia. Support Care Cancer 2005;13:387-92.

12. Cherif H, Bjorkholm M, Engervall P, et al. A prospective, randomized study comparing cefepime and imipenem-cilastatin in the empirical treatment of febrile neutropenia in patients treated for haematological malignancies. Scand J Infect Dis 2004;36:593-600.

13. Viscoli C, Cometta A, Kern WV, et al. International Antimicrobial Therapy Group of the European Organization for Research and Treatment of Cancer. Piperacillin-tazobactam monotherapy in high risk febrile and neutropenic cancer patients. Clin Microbiol Infect 2006;12:212-6.

14. Antoniadou A, Giamerallou H. Fever of unknown origin in febrile leukopenia. Infect Dis Clin N Am 2007;21:1055-90.

15. De Pauw BE, Deresinski SC, Feld R, et al. Ceftazi- 
dime compared with piperacillin and tobramycin for the empric treatment of fever in neutropenic patients with cancer. A multicenter randomized trial. Ann Intern Med 1994;120:834-44.

16. Cometta A, Zinner S, de Bock R, et al. The International Antimicrobial Therapy Cooperative Group of the European Organization for Research and Treatment of Cancer. Piperacillin-tazobactam plus amikacin versus ceftazidime plus amikacin as empric therapy for fever in granulocytopnic patients with cancer. Antimicrob Agents Chemother 1995;39:445-52.

17. EORTC International Antimicrobial Tharapy Cooperative Group. Eficacy and toxicity of single daily doses of amikacin and ceftriaxone versus multiple daily doses of amikacin and ceftazidime for infections in patients with cancer and granulocytopenia. Ann Intern Med 1993;119:584-93.

18. Cornely OA, Wicke T, Seifert H, et al. Once-daily oral levofloxacin monotherapy versus piperacillin/tazobactam three times a day: a randomized controlled multicenter trial in patients with in febrile neutropenia. Int J Hematol 2004;79:74-8.

19. Bow EJ, Rotstein C, Noskin GA, et al. A randomized, open-label, multicenter comparative study of the efficacy and safety of piperacillin-tazobactam and cefepime emprical treatment of febrile neutropenic episodes in patients with hematologic malignancies. Clin Infect Dis 2006;43:447-59.

20. Aydın K, Yılmaz M, Sönmez M, et al. Karadeniz Teknik Üniversitesi Hematoloji Kliniğinde İzlenen Febril Nötropeni Ataklarının Değerlendirilmesi. Flora 2007;12:80-5.

21. Jeddi R, Achour M, Amor RB, et al. Factors associated with severe sepsis: prospective study of 94 neutropenic febrile episodes. Hematology 2010;15:28-32.

22. Gençer S, Özer S, Salepçi T ve ark. Febril nötropenik olgularımızın enfeksiyonlar ve mortalite yönünden değerlendirilmesi. 6. Febril nötropeni sempozyumu, 24-27 Şubat 2005, Program ve Özet Kitabı s.151.

23. Toussaint E, Bahel-Ball E, Vekemans M, et al. Causes of fever in cancer patients (prospective study over 477 episodes). Support Care Cancer 2006;14:763-9.

24. Norgaard M, Larsson H, Pedersen G, et al. Risk of bacteremia and mortality in patients with haematological malignancies. Clin Microbiol Infect 2006;12:217-23.

25. Rolston KVI. Challenge in the treatment of infections caused by gram-pozitive and gram- negative bacteria in patients with cancer and neutropenia. Clin Infect Dis 2005; 40:246-52.

26. Link H, Bohme A, Cornely OA, et al; Diseases Working Party (AGIHO) of the German Society of Hematology and Oncology (DGHO); Group Interventional Therapy of Unexplained Fever, Arbeitsgemeinschaft Supportivmassnahmen in der Onkologie (ASO) of the
Deutsche Krebsgesellschaft (DKG-German Cancer Society). Antimicrobial therapy of unexplained fever in neutropenic patients--guidelines of the Infectious Diseases Working Party (AGIHO) of the German Society of Hematology and Oncology (DGHO), Study Group Interventional Therapy of Unexplained Fever, Arbeitsgemeinschaft Supportivmassnahmen in der Onkologie (ASO) of the Deutsche Krebsgesellschaft (DKG-German Cancer Society). Ann Hematol 2003;82:105-17.

27. Akova M, Hayran M, Unal S, et al. Characteristics of infectious agents in adult cancer patients with neutropenia and fever. 13th Meeting of the International Society of Haematology. Abstract no. 633. 3-8 September 1995, İstanbul.

28. Bodey G, Bueltmann B, Duguid W, et al. M.D. Anderson Cancer Center. Fungal infections in cancer patients: An international autopsy survey. Eur J Clin Microbiol Infect Dis 1992;11:99-109.

29. Fridkin SK. The changing face of fungal infections in health care settings. Clin Infect Dis 2005;41:1455-60.

30. De Pauw BE, Donnelly JP. Infections in the unocompromised host: general principles. In: Mandell GL, Bennett Je, Dolin R, eds. Principles and practice of infectious diseases. 5th ed. Philadelphia: Churcill Livingstone 2000:3079-90.

31. Vazquez JA, Sobel JD. Mucosal candidiasis. Infect Dis Clin North Am 2002;16:793-820.

32. Sain Güven G, Çakır B, Zarakolu P, et al. Febril nötropenik kanser hastalarında tedavi başarısını etkileyen faktörlerin incelenmesi. Flora 2004;9:246-51.

33. Kandemir Ö, Şahin E, Tiftik N, et al. Febril nötropenik kanser hastalarında gözlenen enfeksiyonlar ve tedavi başarısını etkileyen faktörlerin değerlendirilmesi. ANKEM Derg 2006;20:98-102.

34. Segal B.H, Walsh T.J, Holland S.M. Infections in cancer patient. In: DeVita, V.T Jr, Hellman S, Rosenberg S.A, eds. Cancer principles and practice of oncology. 6th ed. Philadelphia: Lippincott Williams and Wilkins 2001:2815-68.

35. Wahlin YB, Granström S, Persson S, et al. Multivariate study of enterobacteria and Pseudomonas in saliva of patients with acute leukemia. Oral Surg Oral Med Oral Pathol 1991;72:300-8.

36. Perez F, Adachi J, Bonomo RA. Antibiotic-resistant gram-negative bacterial infections in patients with cancer. Clin Infect Dis 2014:335-9. 